\title{
Agrarian Conflict, Social Exclusion, and Human Rights Violations in Forest Register 45 Mesuji Lampung
}

\author{
Oki Hajiansyah Wahab ${ }^{1}$, Didiek Mawardi ${ }^{2}$, Rahayu ${ }^{3}$ \\ \{paman_mao@yahoo.com ${ }^{1}$, stihmu.k@gmail.com² ${ }^{2}$ rahayu_undip@yahoo.com ${ }^{3}$ \} \\ ${ }^{1}$ Muhammadiyah University of Metro, Jalan K.H Dewantara No. 116, Metro Pusat, Iringmulyo, Metro \\ Tim., Kota Metro, Lampung 34125, Indonesia ${ }^{1}$ \\ ${ }^{2,3}$ Diponegoro University, Jl.Prof. H. Soedarto, S.H. Tembalang, Tembalang, Kota Semarang, Jawa \\ Tengah, 50275, Indonesia
}

\begin{abstract}
Agrarian conflict in Forest Register 45 Mesuji Lampung which has been going on for a dozen years is a manifestation of contestation on forest area access rights between communities and concession-holding companies. This conflict, in turn, increases not only on the issue of access to forest area management but also the right's ignorance toward citizens who live in the forest area itself. This article raises two issues concerning the dynamics of the politic of ignorance toward citizens in the context of the conflict in Forest Register 45 and the ignorant process that leads to the social exclusion of residents in Forest Regions 45. This article uses a socio-legal approach and the perspectives of Tania Li, Hirsch, and Derek Hall about the power of exclusion. This article concludes that the illegal stigma attributed to farmers who live at the Register 45 forest area becomes the legitimacy of local governments for a politic of ignorance toward citizens' civil and economic and social rights. The politics of ignorance to the fundamental rights of the citizens is done as a series of social exclusion process, which is essentially a violation of human rights.
\end{abstract}

Keywords: Human Rights Violation, Victim Discrimination, Politics of Ignorance, Mesuji

\section{Introduction}

The study of the continuing agrarian conflict is indeed an implication of the past economic orientation and agrarian policy. The establishment of various Sector Laws such as Plantation and Forestry Laws has implications for the increasing variety of rules on the management of agrarian resources. During the New Order era, agrarian policy in the forestry sector of agrarian policy led to the exploitation of forest resources. The mechanism of land acquisition through these rules was implemented through the determination of certain types of rights over land and natural resources within it. Different types of rights have been introduced since the New Order era, including Right to Use" (RtU), Forest Concession (FC), Industrial Timber Concession Rights (ITCR), Mining Work Contracts, etc.[1].

The economic crisis period at the end of the decade of the 90s became a crucial period in the history of forestry in Indonesia. The Center for International Forestry Research (CIFOR) shows that the 1997-2003 periods is a period of significant impact on the dynamics of the forestry sector. This period was the period leading up to and after the change of the New Order regime. The period was a period in which the authority of the security apparatus and law enforcement considerably declined because of the political crisis in Jakarta spread to the regions. Political turmoil in that time also triggered the courage of the people to cultivate on plantation land, forestry, etc. It happened because the people desperately needed land for farming to survive. On the other hand, there was also the neglect of land in the crisis-era with 
various reasons on the rights holders who were affected by the crisis, so they did not have the working capital to cultivate their land.

Management access contestation was the theme of conflict in the forest area, including Lampung. One of the most extended forest management conflicts in Lampung was the conflict in the Production Forest area of Register 45 Mesuji Regency, Lampung. The conflict was triggered by the entry of farmers into the production forest area in the economic crisis period in the late 90s. Their presence as a new social entity began to earn responses in 2006. PT Sylva regains its forest concession rights after being revoked by the Ministry of Forestry due to neglect and inability to manage the concession.

The Forest Area of Register 45 is located in the Mesuji Regency, which is the outcome of burgeoning from Regency of Tulangbawang. The register 45 Sungai Buaya was defined as forest area through Resident Besluit number 249 on April 12 $2^{\text {th }}$ 1940, with the vast 33,500 hectares.

The forest from the ground clan /traditional /land was handed over to the state to be a forest area, by not entering the hamlet/gutters/pennant/villages as settlements and arable land in the surrounding areas which were designated as forest area. The formation of these lands are by the public submission of GunungTalang to the Resident Lampung 1940 vide Bewijs van Aanstelling that has been represented by BAHOESIN GELAR TOEAN PESIRAH with documentation /letter dated March 9, 1941 number 20/1941.

In 1985, the measurement and construction of definitive boundaries against the forest area of Registers 45 had been implemented. Based on Forest Use Agreement of the Province of Lampung on July 12, 1980, recommendations Governance Limits/ The Inaugural Forest, and Bapedda Lampung I number Ek 000/279/Bappeda/II/1985 dated June 13, 1985, the Committee of the system limits is led by the Regent of North Lampung did setting up of the boundary with the construction announcement procedure limits.

The end result stated in the document of the measurement boundary demarcation which was signed by the committee boundary that was led by the head of the Forestry Office of Dati I Lampung, the head of the Forest Inventory and Mapping Region II, governor KDH Tk I Lampung, and the head of the Agency for Inventory and Forest Land Use, and the Minister of Forestry has authorized it. The Governor of Lampung through issuing the letter-number 525/313/Bappeda/1989 proposed to the Minister of Forestry for the forest area of Register 45 would be decided to be production forest area of 43,100 hectares.

Furthermore, on October 7, 1991, Decree (SK) Minister of Forestry number 688/KptsII/1991 was just issued. The Minister of Forestry provides forest concession rights to acreage crop industries (HPHTI). PT Inhutani Silva Lampung (SIL) in 45 Register Sungai Buaya Lampung owns around 32,600 $\mathrm{m} 2$ hectares. PT SIL is a joint venture between PT Silva Lampung Abadi PT Inhutani V. Then, Decree of HPHTI for Regional Register 45 came out. The ministerial decree number 93 / Kpts-II / 1997 showed the determination of forest area of Register 45 covering 43,100 hectares. This area was formally designated as forest areas with the concept HPHTI. The commodity planted was acacia tree.

The economic crisis that hit Indonesia at the end of the '90s before the reform, causing many companies went bankrupt. Companies engaged in forestry areas experienced the same case. Due to the crisis, abandonment of land leads to concession rights, as well as the concession of PT SIL as the holder of HPHTI in Register 45. The impact of the economic crisis was also experienced PT SIL, which resulted in HPHTI revocation by the Government in 2002 through the Decree of the Minister of Forestry number 9983/Kpts-IIV2002.

The economic crisis in that period causes many companies to slow down on its business activities. In 1997, a group of farmers came massively due to the abandonment of land. During 
this period of economic crisis, many companies slow down the activities of their business. As a result, many land abandonment occurred. The farmers slowly took over into the area. They managed and developed the land and building the settlements. In general, the tenants who inhabited the area of Register 45 are composed of three major ethnicity groups, the people of Java, Bali, and other tribes. Most of the tenants came from transmigration areas, which is in the province of Lampung.

During this period, the newcomers open and cultivate the land with a specific type of cassava plant, and they have not established a home to settle down. The yields during this period were used as capital to build houses and other facilities. In addition to planting cassava, the tenants also planted rubber and keeping of animals. All of which is intended for the benefit of subsistence. Until now, there are five areas as village level, namely Moroseneng, Morodadi, Morodewe, SukaMakmur, and Asahan. The society gives the names of the village on their own.

However, the company filed a lawsuit against the decree to the court and won the lawsuit. The Minister of Forestry also issued a ministerial decree number 322 / Menhut-II / 2004 on Revocation of the ministerial decree number 9983 / Kpts-II / 2002 and the reenactment decree number 93 / Kpts-II / 1997 concerning Provision HPHTI over Forest Areas covering an area of 43,100 hectares to PT SIL. Surprisingly, in a decree number 322, the acreage of the HPHTI PT SIL became 42,762 hectares.

The obscurity of the area Register 45 and various problems of determination of forest area in the past became the root of the agrarian conflict in the following days. Also, the citizens of Moro-Moro, a group of indigenous people claim the expansion of the forest area at Register 45 in the past have taken their indigenous land. The Indigenous communities, who feel that their land was taken away due to the expansion of the forest area of Register 45, made ranging efforts from filing lawsuits to the court up to attempting to occupy the land.

District Government attached illegal stigma and encroachment to residents who lived in the production forest area. This had a direct impact on the recognition and fulfillment of the fundamental rights of citizens, such as the right to education, health, identity, politics, and various other rights. The access question to conflict forest areas in Forest Register 45, in turn, spawned a variety of socio-juridical issues. Agrarian conflict in the production forest area of Register 45 Mesuji Lampung which had been going on for a dozen years was a manifestation of contestation of forest area access rights between the community and the concession of Holder Company. Ultimately, this conflict developed not only on the issue of forest area management access but also the constitutional right's ignorance of the citizens living in the forest area[2].

The case experienced by the citizens of Moro-Moro could be said as an attempt of exclusion in social status, political, and economy, which is marked through the absence of recognition of the State. Realize it or not, the state also discriminates in the fields of political, economic, legal, social, cultural, and other aspects of life. The case of losing the political rights of the citizens in various election processes as experienced by the people of Moro-Moro Register 45.

This article raises two issues concerning how the politics of ignorance toward citizens is born in the context of the conflict in Register 45 Forest Area and how the ignorance process and human rights violation that occurred is related to the social exclusion process of citizens in Register 45 Forest Area. 


\section{Method}

This article uses a socio-legal approach by integrating legal drafting and other social sciences in viewing and assessing reality. Through this approach, it is possible to use various approaches to overcome some theoretical and methodological limitations of related disciplines to develop a new form of analysis[3]. Primary data were obtained through in-depth interviews and brief observations of secondary data, which was collected through documentation and library search studies.

\section{Findings: Preliminary}

\subsection{Conflict Area in Forest Register 45 Mesuji, Stigma, and Its Impact}

The tide of the conflict in Forest Register 45 Mesuji has occurred in the last ten years. The issuance of Minister of Forestry Decree Number 322/Menhut-II/2004 on the revocation of Minister of Forestry Decree No. 9983/KPTS-II/2002 and the re-enactment of Decree No. 93/KPTS-II/1997 which is a permit of PT Sylva forest exploitation caused the company to expel the residents of the forest.

Before the Mesuji case emerged as a civil case at the end of 2011, in the local level, a Special Committee of the Forest Register 45 had been made which had provided recommendations in the resolution of cases in the Register 45. Recommendations by recommendation were issued, but none of them were implemented. Subsequently, TGPF Mesuji's recommendations were considered to be the ultimate resolution for the bloody conflict at Register 45.

The recommendation of a team formed by the Coordinating Minister for Political, Legal, and Security Affairs which clearly stated that there had been a violation of the citizens' constitutional rights and recommended that the recognition of the rights of the people was not working. The illegal status and encroachment attached to the residents who lived in the production forest area had the effect of not recognizing their constitutional rights. One language pack is then crammed into them, articulated in the newspapers, discussed, socially legitimized, and reinforced politically.

The actors in conflict in Register 45 Mesuji - Lampung have an interest in each goal which relates to the protected forest as a resource for grabs. The mechanism of the parties who are involved reclaiming in acquiring, controlling, and maintaining the flow of benefits from the forest products and its distribution is such ability access that is influenced by technology, capital, markets, knowledge, authority, social identity, and social relations.

The stigma seemed to justify the disapproval of the State. For a dozen years residing in the Forest Register 45, The Moro-Moro citizens have no identity card and also lost their political rights to get involved in the election. Living in an area of agrarian conflict with illegal stigma was indeed full of vulnerability, not only being denied of access to education, but also a variety of other access such as health access, which was constitutional rights. The local government strongly argued that under Law 23 of 2006 on Population Administration, they could not be categorized as residents because they live in forest areas even though they have a community entity like a village for a decade. They are also considered to violate Law No. 41 of 1999 on Forestry.

It is through that stigma and ignorance, individuals or groups of people, their life is cut off from the services, social networking, and growth opportunities for a decade, which is enjoyed by most people in general. Living in an area of agrarian conflict and living with illegal stigma 
is indeed full of vulnerability, not only access to education but also a variety of other accesses such as health access, which is a constitutional right, is obstructed.

Illegal stigma emerges as part of the practice of the state to present the principles of legality and then put it in opposition to the illegal narrative. Illegal narrative or illegality narrative includes labeling on a particular group or behavior that arises, and it is distinguished from general conditions as a categorization created by the state[4].

On the other hand, law enforcement against those who allegedly entered the forest area continues to be done. What about law enforcement against violations committed by HPHTI, the holder of companies? TGPF reported, Mesuji Case conveys various offenses done by ultimately Inhutani Silva. Finally, the points of view will imply that the treats toward the actors are being involved in the conflict.

Basically, in order to utilize the objects of natural resources, both governments and the private sector or the public benefit 'compete' in access and benefit as much as possible. Government, private, and community are actors who usually always existed in various forms of conflict and agrarian issues or natural resources in Indonesia. Here, contestation is defined as a dynamic process of the parties or actors who interact and mutually negotiate what is its importance in the context of the struggle for natural resources. Conflict in the register 45 is a conflict contestation of control and management of industrial forests that have long become cross disputes between investors, communities, and government. The changing government policies, the uncoordinated and minimal government supervision, the investors who do not perform the duties, incompetence, the abuse of permits granted, the rage of the people being knocked out, and the operation of land speculators have caused disputes in Register 45 for years and the problem has yet to wholly resolved.

\subsection{Ignorance, Social Exclusion, and Human Rights Violations}

The economic crisis that hit Indonesia in the late 90s became a turning point in forestry conditions in various places. The economic meltdown opened opportunities for people to manage the forest area that many neglected due to the economic crisis at that time. That was what seemed to be an illustration of how the conflict in the Forest Register 45 Mesuji born and grew.

Since their first time arriving at Register 45 at the end of 1996, the people of Moro-Moro have a problem with their identity rights to be recognized as a citizen of Indonesia. As a part of entities living in Indonesia, Moro-Moro residents were ignored by the state through not having any identity cards. In the case of the Moro-Moro, it can be seen that the waiver that was done by the government has already implicated on the difficulty of fulfilling the constitutional rights and legal rights for citizens of Moro-Moro. Such abandonment conducted by the government can be identified as an act of discrimination.

The Article 63 Paragraph (1) of Law No. 23 of 206 states that the people of Indonesian and Foreigners who have a fixed residence permits that have been aged 17 years or have been married or ever married are required to have National Identity Card (KTP). The right to civil on documentation ID is conceptually included in a clump of civil rights and political, but it impacts on the respect, fulfillment, and protection of the rights of economic, social, and cultural.

The actual residence document is access to the fulfillment and protection of the rights of economic, social, and cultural. The people who are living without ID cards will have difficulties to make a driver's license (SIM), get health insurance (Health Guarantee), and various other government assistance programs. The children who are born in the territory of 
the forest Register 45, since in the womb already felt the pressures of life due to the severity of the waiver policy of constitutional rights. Whereas, Article $28 \mathrm{~B}$ paragraph 2 of our Constitution states that every child has the right to survive, grow, and develop, as well as the right to be protected from violence and discrimination.

In the case of the Moro-Moro, the Government also has discriminated the children of Moro-Moro. The government deliberately ignored the constitutional rights and legal rights of children that are protected by the Constitution and various other legislations. None of the children in the world ever desired being born in the territory which is considered as a problematic place. None of the children could choose to be born in the forest and grew up there. The State should also give rights to children who would very likely be able to boost the country with its contribution to the nation.

The conflict in the Forest Register 45 Mesuji uttered a "politic of ignorance" and social exclusion which were carried out through power, regulation, pressure, and legitimacy[5]. Social exclusion itself is a process and a result. Social exclusion is a process when there are obstacles from institutions in the achievement of life necessities, human development, and equal rights as citizens. Meanwhile, social exclusion is a result when individuals or groups are not able to fully participate in the society because of social identities such as ethnicity, gender, caste or religion, and locations like inland areas, war zones, or conflict areas.

Denial of the citizens' rights and the lack of social citizens' rights is also an indicator of the occurrence of the social exclusion process. The process of stigmatization, oppression, and restriction through policy and other institutional discrimination made individuals or groups excluded from social, political, and cultural life[6][7]. These delectations ultimately lead to a process of social exclusion.

Discrimination towards actors who are involved in the conflict in Register 45 is motivated by the status of a claim, historical background, and strategy which was developed by the community groups that are involved in the conflict. Discrimination is done to prevent the merging of the three communities in a conflict that is feared to complicate the process of conflict resolution in Register 45 further.

Discrimination being questioned here is how this discrimination relates to network and bundle power. The discrimination is ultimately expressed in the choice of social action in the context of controlling interest and maintaining access. The process of exclusion community on the outskirts of the forest area is not just related to the issue of the regime and relations of unequal power between corporations and governments with communities of rural farmers. It is also associated with the paradigmatic domain or wake-stacking of knowledge that settles in the 'ideological' system, which is adopted by the authorities in taking care of the arrangement of space in the forest area.

This exclusion is interdependent with other groups which have more economic exclusions. The removal of a group of people from the land may start with a process that limits them to other rights, such as the right to public services like electricity, education, health, clean water, road access, and so on. The excluded person will find it difficult to access the aspects that can support their life, such as social, economic, political, and even educational aspects. It also automatically breaks down social networks and opportunities for the development of individuals to gain a better life.

Indonesia, as a state that has adopted human rights protection in its constitution, is undoubtedly responsible for this kind of situation. As a state of law, the government should guarantee the law as an instrument for realizing social justice. The law must be able to regulate the security to protect, respect, and fulfill citizens' rights without any discrimination. 
The 1945 Laws of the Republic of Indonesia also prohibits various acts of discrimination, as reflected in Article 27 paragraph (1), Article 28D paragraph (1), Article 281 paragraph (2).

Prohibition on discrimination is also reflected in Article 1 paragraph (3) of Law No. 39/1999 on Human Rights, in which one cannot justify discrimination based on religious, ethnic, racial, group, social status, economic status, gender, language, and political beliefs. Article 28 I Paragraph (4) of the 1945 Laws of the Republic of Indonesia also shows the responsibilities of the state to respect, protect, and fulfill human rights. Also, Article 28 Paragraph (5) affirms the enforcement and protection of human rights by the principles of a democratic constitutional state.

The constitutional rights are rights that are guaranteed by the Constitution of 1945, while legal rights (legal rights) arose under the guarantee Act and the regulations under it (subordinate legislation). After the provisions on human rights were adopted in full in the Constitution, the notion of human rights and the rights of citizens can be associated with the notion of "constitutional rights" guaranteed in the Constitution 1945. Also, every citizen of Indonesia owns legal rights in detail and operational activities which are regulated by law or other legislation that is lower. Rights born outside of the regulations of the Constitution refer to legal rights (legal rights), not constitutional rights (constitutional rights).

The practice of power which tends to be manipulative and silence the actualization of human rights protection, will tarnish the sovereignty of the people. In response to these conditions, a critical consciousness about the idea of constitutionalism appeared. The essence of the idea and the concept of constitutionalism is the existence of State law (the rule of law) and the appreciation and protection of the human freedom, as well as that, was limited by the power of the state.

\section{Conclusion}

Conflict in Production Forest areas of Register 45 Mesuji is essentially a manifestation of the importance contesting towards forest enterprises access between the company and the community. The tide of existing conflict resulted in an illegal stigma and encroachment which is attached by the government to drive the Moro-Moro people to suffer an ignorance of their fundamental rights, which are regulated and protected by the constitution and various laws and regulations in Indonesia.

The tide of the conflict in the Forest Estate Register 45 Mesuji of Lampung has spawned a "politics of ignorance" (political negligence) and social exclusion. Abandonment experienced by the citizens of Moro-Moro is primarily a social exclusion process through rule, regulation, pressure, and legitimacy. The politics of ignorance practiced by the Mesuji Regency government is essentially a series of social exclusion processes that are run through power, regulation, pressure, and legitimacy. The loss of citizens' rights to get an education, health and other crucial rights proves that there has indeed been a violation on the social, economic, and cultural rights of the citizens, which is committed by the Mesuji Regency Government.

\section{ACKNOWLEDGMENTS}

The author would like to thank Prof. Dr. FX AdjiSamekto, Dr. HS Tisnanta for various inputs, comments on this paper. This paper was developed from a paper entitled 'Failed Stated, Critics on People Constitutional Rights Ignorance in Moro-Moro, Register 45 Forest, Mesuji Lampung' presented at the Asian Student Law Institute (ASLI) at National Law School of India University, Bangalore, May 23-24 2013 


\section{References}

[1] S. M. Borras Jr, "Toward A Better Understanding of Global Land Grabbing: An Editorial Introduction,” J. Peasant Stud., vol. 38, no. 2, 2011.

[2] S. Suyanto, "Underlying Cause of Fire: Different Form of Land Tenure Conflicts in Sumatera,” Mitig. Adapt. Strateg. Glob. Chang., vol. 12, no. 1, 2007.

[3] T. Banakar, Theory and Method in Socio-legal Research. New York: Hart Publishing, 2005.

[4] J. Mc Charty, The Limits of legality. State, Governance and Resource Control in Indonesia In The State and Illegality in Indonesia. Leiden: KITLV Press, 2011.

[5] C. R. Hayward, "Responsibility and Ignorance: On Dismantling Structure Injustice," J. Polit., vol. 79, no. 2, 2017.

[6] M. McCann, Law, and Social Movements 1 st Edition. London: Routledge, 2017.

[7] Pierson, Tackling Social Exclusion. London: Routledge, 2002. 